\title{
Nuclear Technology and the Space Exploration Missions
}

Henry W. Brandhorst and Ronald J. Sovie

\author{
NASA Lewig Research Center \\ Cleveland, OH 44135
}

\begin{abstract}
The strategy for a major exploration initiative leading to permanent human presence beyond earth orbit described by President George Bush July 20, 1989 is still being developed; however enough is known to begin defining the role of nuclear technologies. Three broad areas will be discussed: low power $(<10$ kWe $)$ rover/vehicle power systems, integrated, evolutionary base power systems $(25-100 \mathrm{~kW})$ and nuclear energy for electric propulsion (2100 MWe) and direct thermal propulsion (1000s MW). A phased, evolutionary approach will be described for both the moon and Mars, and the benefits of nuclear technologies relative to solar and their integration will be described.
\end{abstract}

\section{INTRODUCTION}

The Pregident of the United States has established a long term course for the human exploration of space. Beginning with the space station Freedom in the 1990 s and, in the next century, returning to the moon, establishing a permanent presence, and using the experience and technologies gained from these misgions to move on to the exploration and habitation of Mars. Following the Presidents' speech of July 20, 1989, the NASA performed detailed studies of a variety of mission scenarios and architectures to accomplish these missions and identified the key technologies needed to bring these missions to fruition. In this paper, we will discuss the various mission scenarios and approaches, the key technological requirements for power and propulsion and the potential benefits of nuclear technology for meeting these requirements.

\section{MISSION SCENARIOS}

A variety of Exploration Options were considered during the 90-day study. These options considered various approaches such as vigorous deployment and early landing on the moon, the earliest possible landing on Mars, reduced logistics from earth, delayed program start, and paced deployment. The Exploration option that received the most study and that will serve as the reference for this paper is depicted in figure 1. In this approach, we build upon our past and present investments in space such as Apollo, Shuttle and the Space Station Freedom, employ robotic and manned craft and emphasize science. The key point is, however, that we build a lunar outpost first and learn to live on planetary surfaces before moving on to Mars. The lunar/Mars exploration strategy will be implemented in three phases: Emplacement, Consolidation and Utilization. The key elements and objectives of a typical evolution strategy are shown in figure 2. In this figure, the activities are shown as a function of time as one moves to the right. A number of key elements have been identified as critical for implementing this strategy and they are shown in figure 3 . The critical 
items and technologies of interest in this paper are the rovers, surface vehicles, surface power systems, science outpost power systems and propulsion systems for Mars. The role of nuclear energy in fulfilling these needs will be discussed below.

\section{POTENTIAL ROLE OF NUCLEAR ENERGY}

Vehicles: Figure 4 depicts a pressurized manned rover that is outfitted for long distance traverse on the lunar surface. The power level is nominally $7 \mathrm{~kW}$ and the cabin retains a shirtsleeve environment. Figure 5 depicts a vehicle used to haul regolith to an oxygen processing plant. Here the power requirement is a nominal $3 \mathrm{~kW}$ with $15 \mathrm{~kW}$ peaks. The power source shown for these applications is a dynamic isotope power source either on a cart at the rear of the vehicle or integrated into the structure. Figure 6 shows more design details. Other potential applications include remote observatories or other remote or mobile aystems. Non-nuclear systems such as photovoltaics and/or fuel cells or batteries remain as viable options where the distances and/or the storage time is short enough to keep the system mass low.

Surface Power: Figure 7 outlines
several options for stationary
surface power systems.
scenarios include an installation powered by solar cell and regenerative fuel cell systems which reach about $75 \mathrm{~kW}$, then a transition to nuclear reactor-based systems providing 100-1000 kw. It is important to note that these hybrid syotems are attractive for the additional reliability they provide for the human presence. Nuclear reactor systems are felt to be essential for the lunar application because the $354 \mathrm{hr}$. night is too long for mass-effective storage systems. For Martian applications where the night is only 12 hours long, photovoltaic/regenerative fuel cell oystems remain competitive.

Propulsion: Nuclear thermal rockets compare directly with the chemical propulsion systems but offer substantially higher specific impulse (2-10X). Two main approaches have been taken to the nuclear thermal propulsion system - solid core and gas core reactors. Solid core reactor technology was demonstrated through the NERVA engine tests of the '708, while gas core reactorg have been extensively studied. Power levels of these systems are on the order of 1000 MWth.

Electric propulsion gystems range from 2-10 MWe and 50-100 MWe. The primary difference between this approach and thermal or chemical systems is that the thrusting is continuous over the mission duration and, most importantly, substantial electric power is available for use once the destination has been reached. This power could be used to perform better science as well as for higher power communications to improve quality or to provide power to the surface. Furthermore, the life of these systems may well be such that multiple missions to Mars could be made with one reactor system.

\section{NUCLEAR TECHNOLOGY BENEFITS}

Vehicles: The primary benefit of a dynamic power conversion unit is to conserve $\mathrm{Pu}^{238}$ and to provide a more compact unit. specifically, a $5 \mathrm{kWe}$ unit with a $16 \%$ efficient Brayton conversion unit weighs $826 \mathrm{~kg} \mathrm{as}$ shown in Fig. 6, compared to a 500 We radioisotope thermoelectric generator (RTG) system welghing $170 \mathrm{~kg}$. The $\mathrm{Pu}^{238}$ inventory is reduced about threefold over that required by the RTG of equivalent power. Compared to solar or fuel cell powered vehicles, 
isotope dynamic systems offer virtually unlimited range as well as sunlight independence.

Surface Power: Figure 7 also compares the mass of advanced solar to nuclear options on the moon. Power system mass savings for nuclear oystems are a factor of 5 at $100 \mathrm{kWe}$ and a factor of 10 at $550 \mathrm{kWe}$. When one considers the total mass transported to LEO, the benefits of these advanced solar systems over atate of the art solar are shown in figure 8. Mass savings for advanced solar gystems are about $110 \mathrm{MT}$ at 100 kWe. Figure 9 shows a rendition of a lunar base using advanced solar cells and cryogenic storage of the $\mathrm{H}_{2}$ and $\mathrm{O}_{2}$ regenerative fuel cell reactant 8 .

Figure 10 shows that nuclear systems gave over $100 \mathrm{MT}$ at the $100 \mathrm{kWe}$ level when compared to the advanced solar systems and over $1100 \mathrm{MT}$ at the 800 kWe level for lunar applications. At Mars, the savings are somewhat less because of the reduced night. Figure 11 depicts a hybrid lunar base with a $100 \mathrm{kWe}$ photovoltaic/regenerative fuel cell gystem coupled with an 800 kwe nuclear-stirling power system.

Propulsion: Figure 12 demonstrates the mass savings to LEO for a variety of nuclear propulgion options. Solid core reactor (SCR) systems save almost 408 of the mass required for a chemical/aerobrake system. Adding an aerobrake to the SCR leads to mass savings of 508. This is equivalent to the benefits of a regeneratively cooled gas core reactor (GCR). Radiative cooling gives additional benefit. These cases all had the same 434 day trip time. One other major benefit of nuclear systems is that trip times can be shortened substantially. As shown, trip times of 180 days can be attained with mass saving of 218 while with an increase of about 308 in mass to LEO, trip time can be shortened to 120 days.

\section{KEY TECHNOLOGIES}

These ambitious missions to ensure permanent human presence in space rely on several key technologies for success. Some of them have been outilned above - aerobrakes for planetary capture, advanced chemical propulaion for epace engines, and nuclear power for a mature lunar outpost. other key technologies include reusable transfer and excuraion vehicles, closed loop life support systems, oxygen production from lunar soil and radiation protection/warning. These are all assumed to be successful for the reference approaches that have been studied to date.

There are additional high payoff technologies that pertain to the Mars mission. These include advarced nuclear propulaion and reduced gravity countermeasures. From these lists it can be clearly seen that nuclear power plays a critical, sustaining role in the permanent human presence in space. There are significant technological challenges that must be surmounted before these systems can come to fruition.

\section{CONCLUSIONS}

The lunar/Mars initiatives and their corollary precursor missions offer the nation and the world an exciting new challenge. Numerous mission scenarios have been studied and no insuperable barriers have been identified. As a result of these studies, it is clear that nuclear power offers significant potential benefits from kWe class applications to 1000 of wWth propulsion missions. These studies have also pointed the way to the major technologies that should be developed to enable these missions. Development programs for these key technologies are underway. 


\section{Exploration Approach}

Build upon past and present investments in space
c Apollo, Viking, elc.
D Space Shuttle
D Space Slation Frcedom

Employ robotic craft along with manned systems

Emphasize science along the way

Build a lunar outpost first

D Research base for sclence and lechnology

D Tesibed for humans to Mars

Explore Moon and Mars in phases

o Emplacement $\rightarrow$ Consolidation $\rightarrow$ Operation

Evolutionary approach to realizing Space Policy goal of "Expanding /uman presence and activity

beyond Earth orbit into the solar system"

Figure 1. Exploration Approach

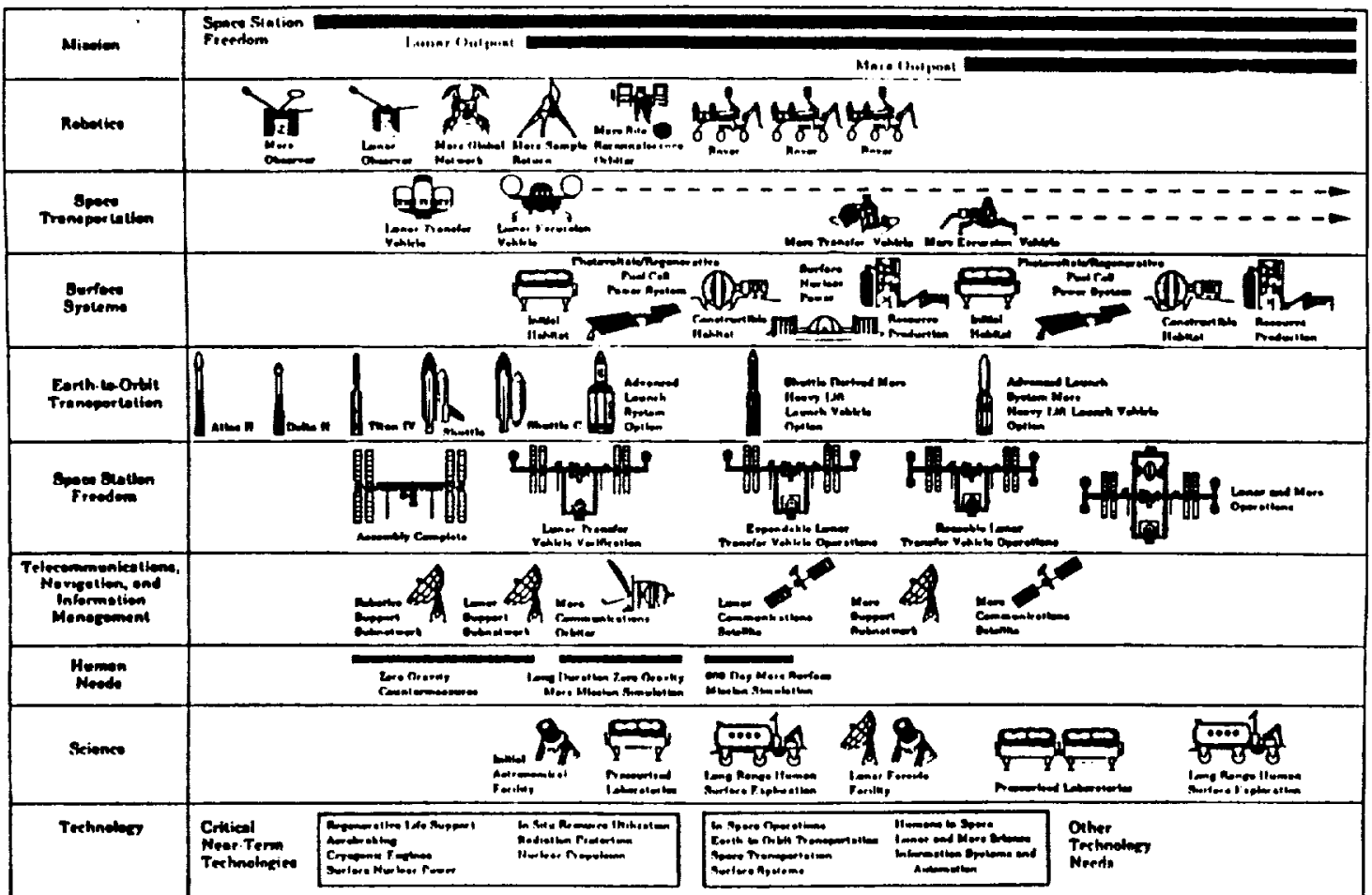

Figure 2. Space Exploration Elements 


\section{TYPICAL EVOLUTION STRATEGY}

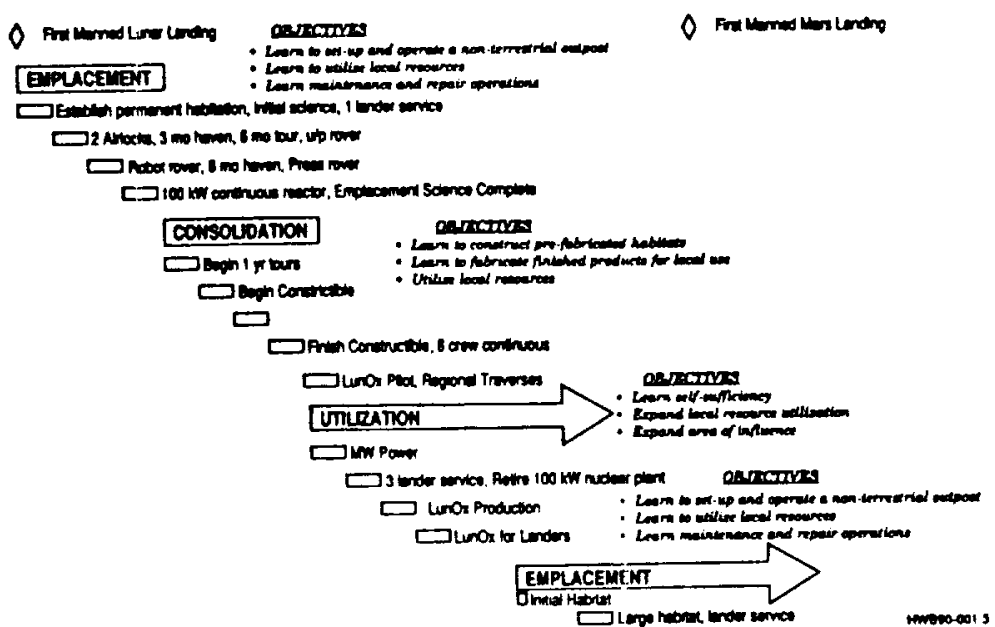

Figure 3. Evolution Strategy

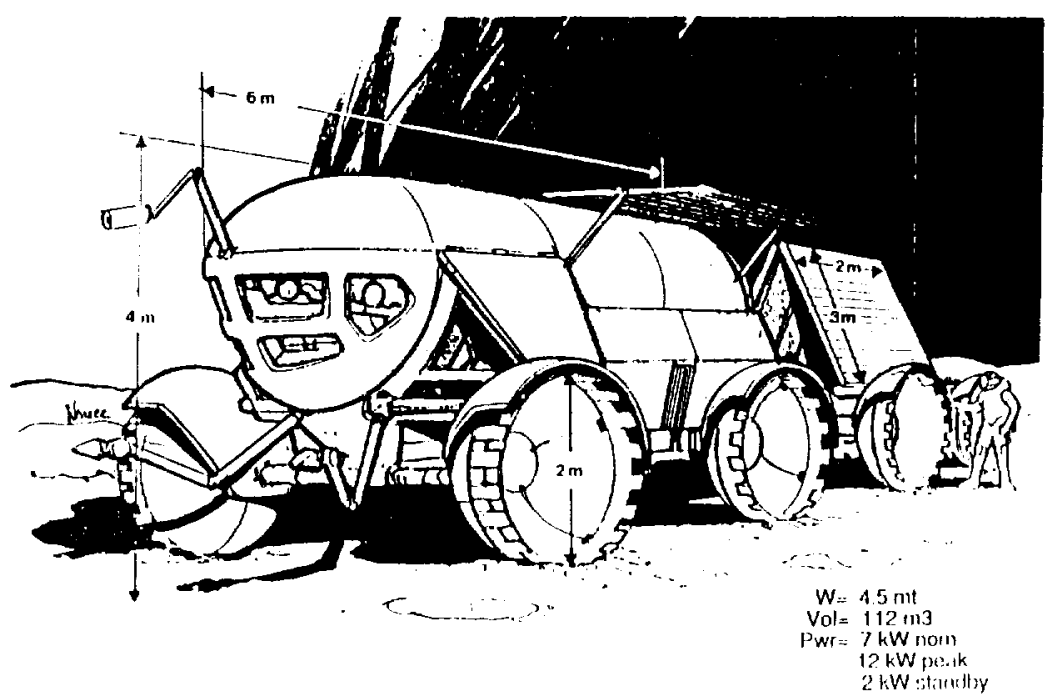

Figure 4. Pressurized Manned Rover 


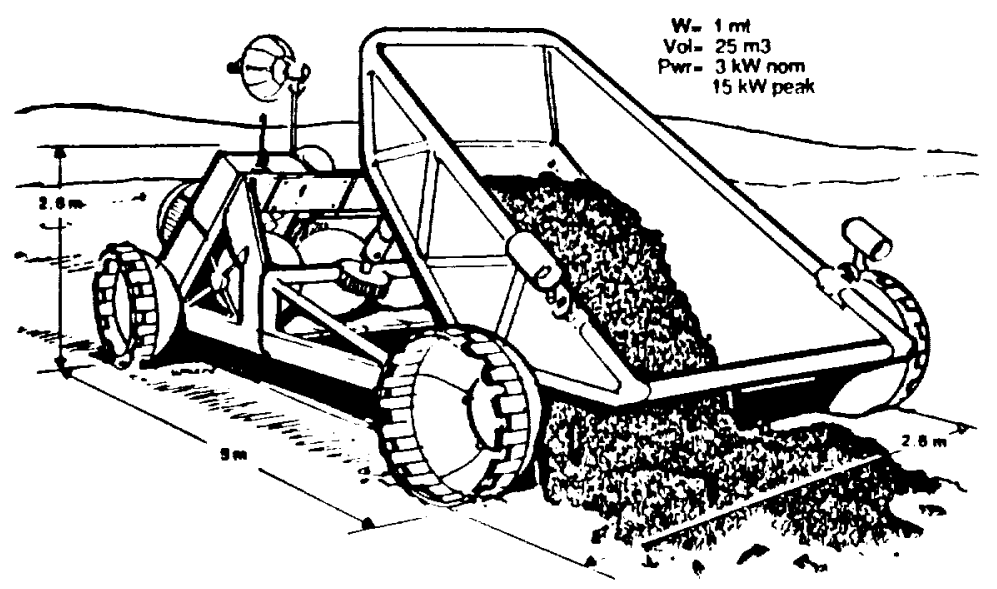

Figure 5. Regolith Hauler

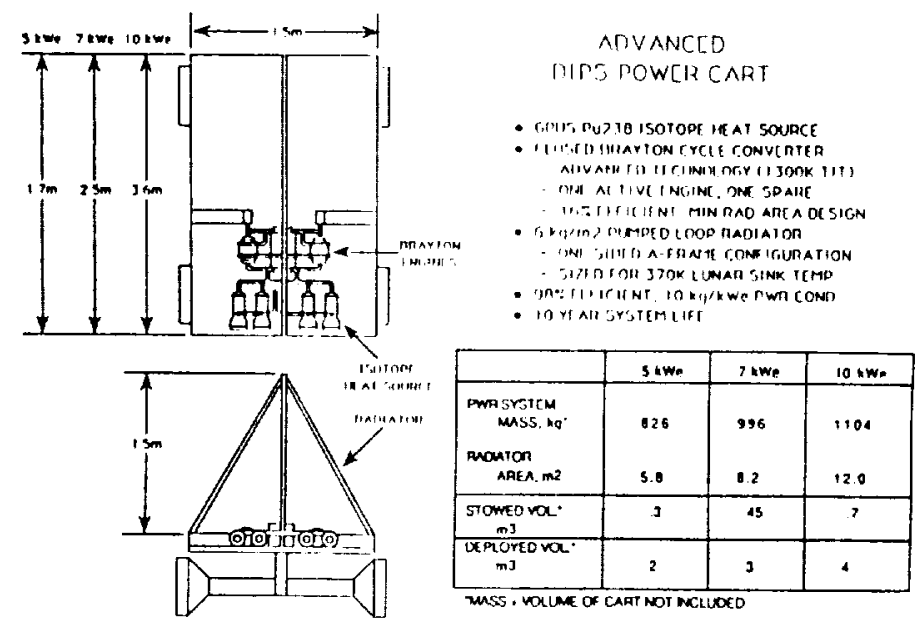

Figure 6. Dynamic Isotope Power Source 


\section{LUNAR/MARS EXPLORATION INITIATIVE \\ SURFACE POWER SYSTEMS}

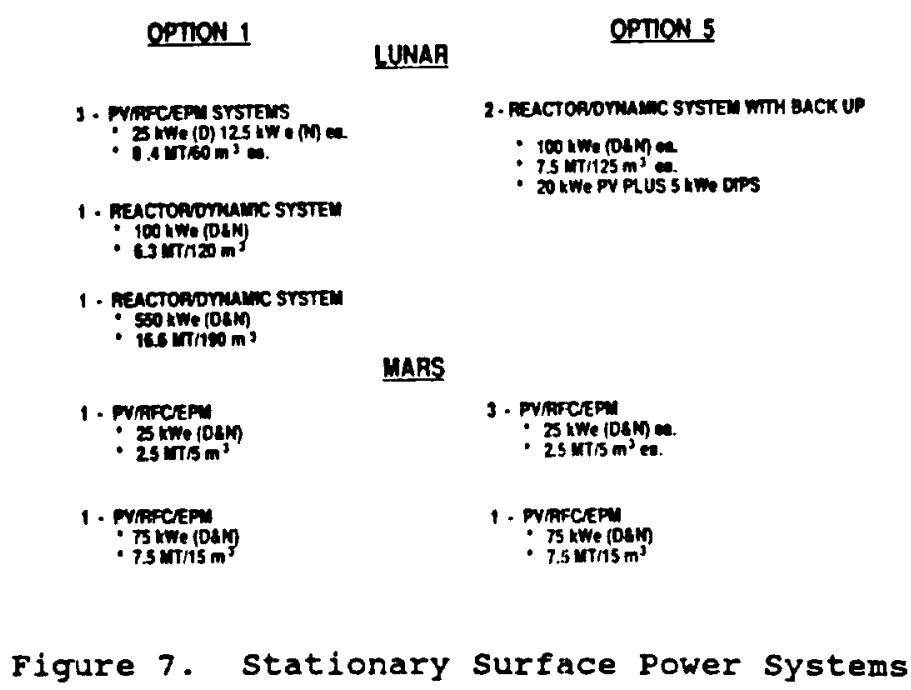

\section{Mass Savings to LEO of Advanced Solar Power rs. SOA Solar Power}

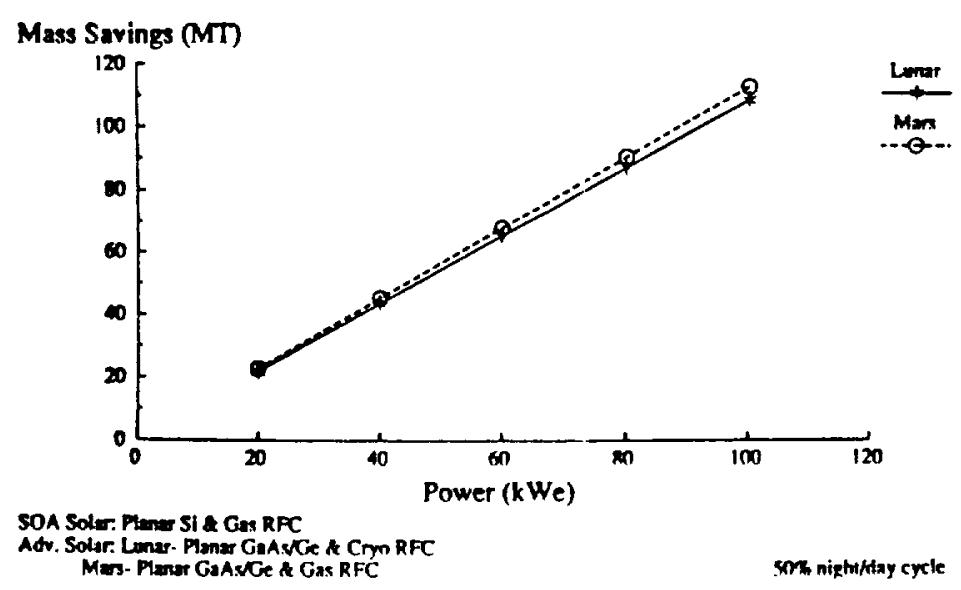

Figure 8. Mass Savings of Advanced
Solar Technologies 


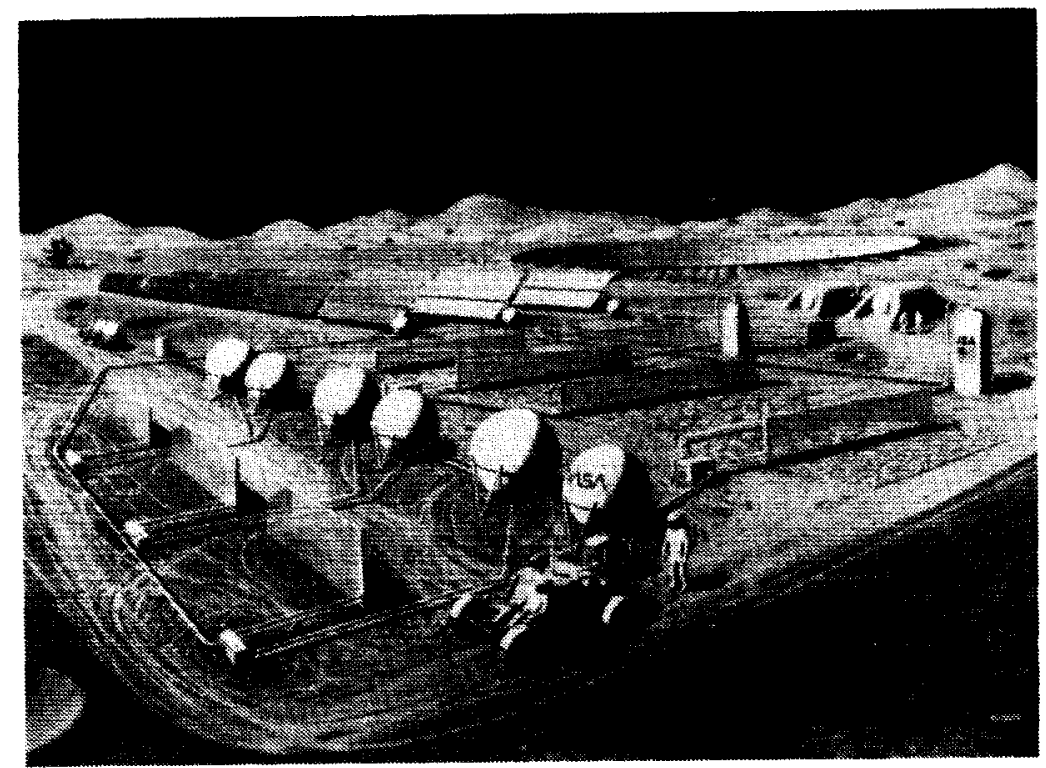

Figure 9. Solar-based Lunar Power System

\section{Mass Savings to LEO of Nuclcar Power}

vs. Advanced Solar Power

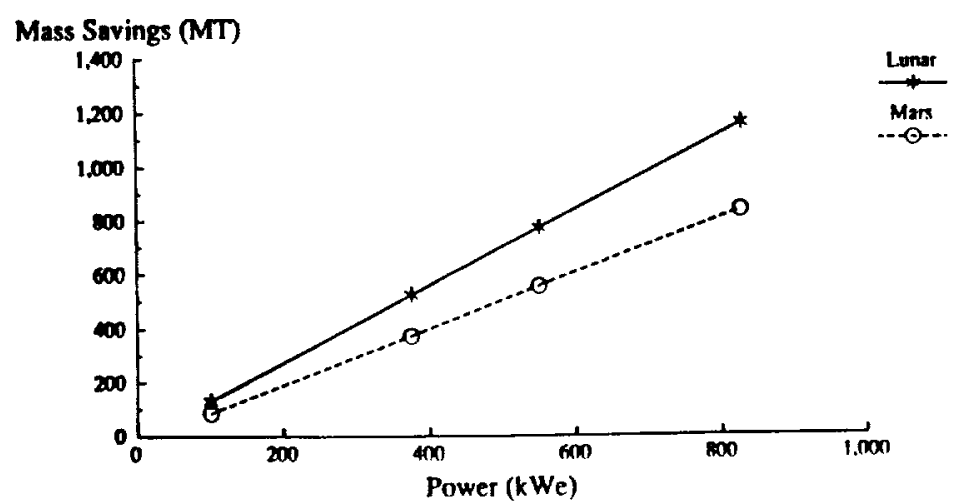

Adv. Solvr. Loner-Planar GaAs/Ge \& Cryo RFC

Mar.Plana GaAske \& Gascous RFC
Nuclear. SP.100 w/ $1300 \mathrm{~K}$ Stirling

100 nighi/day cycle

Figure 10. Mass Savings of Nuclear Power Systems 


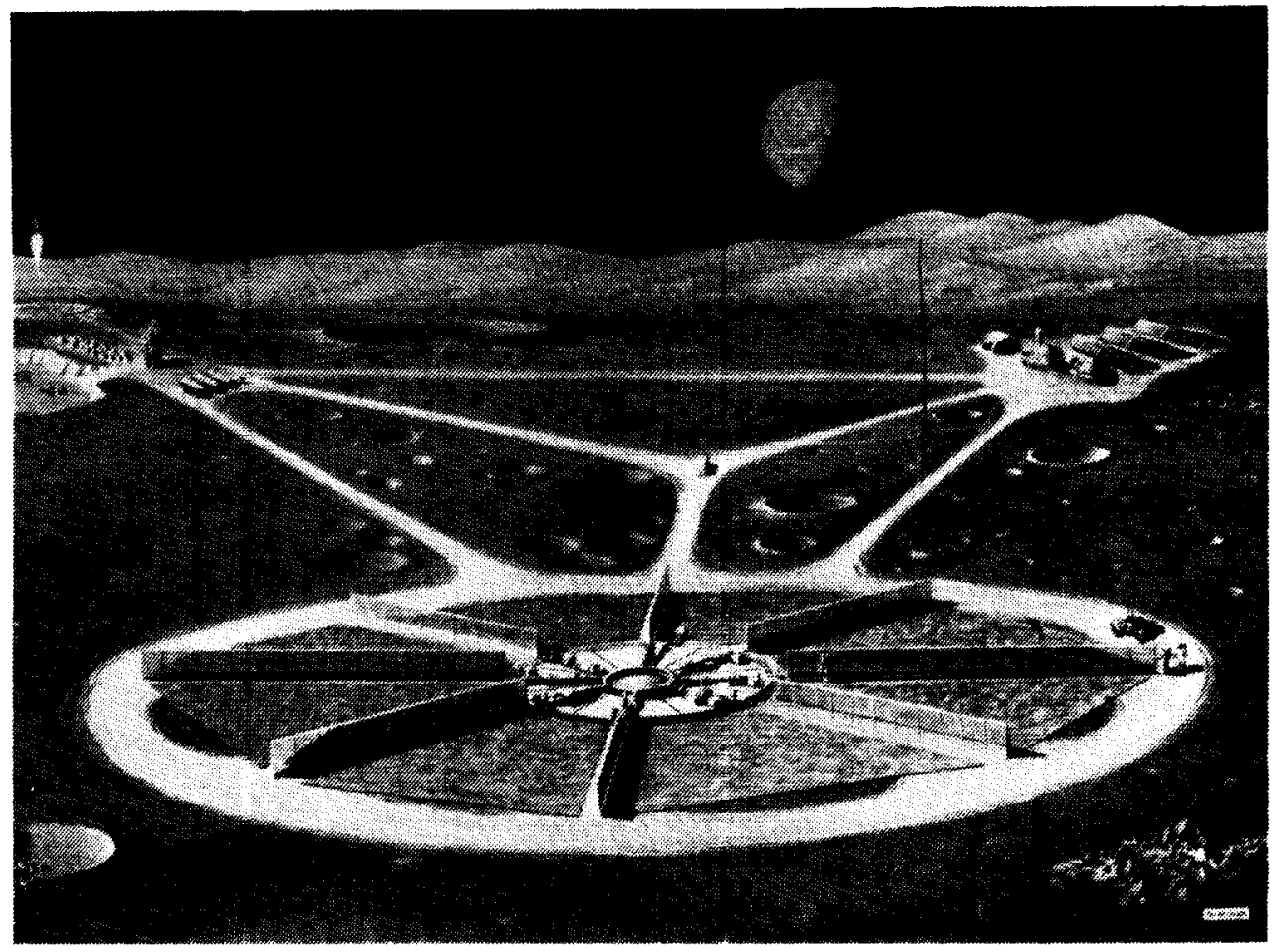

Figure 11. Hybrid Powered Lunar Base

PROPULSION PERFORMANCE COMPARISON SCR AND GCR PILOTED MARS MISSIONS, QUICK TRIPS PQDAY EXPLORATION INITATIVE

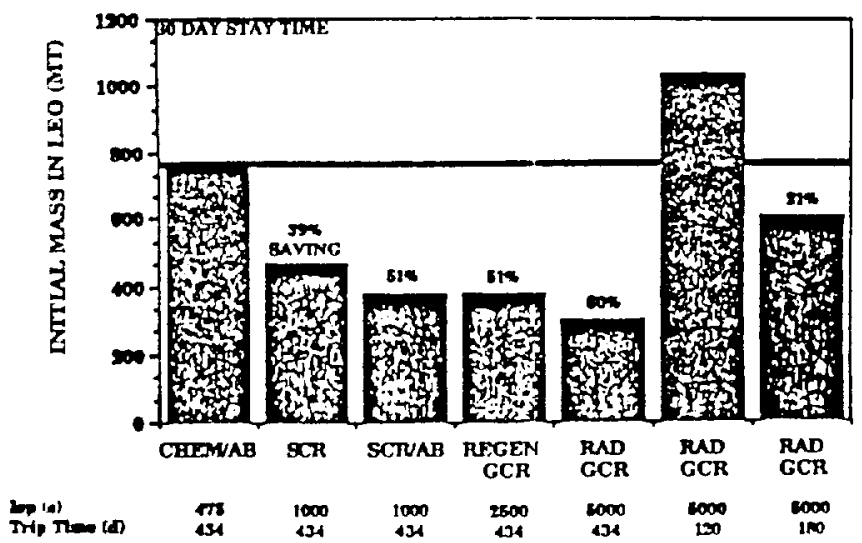

Figure 12. Nuclear Propulsion Mass Savings to LEO 


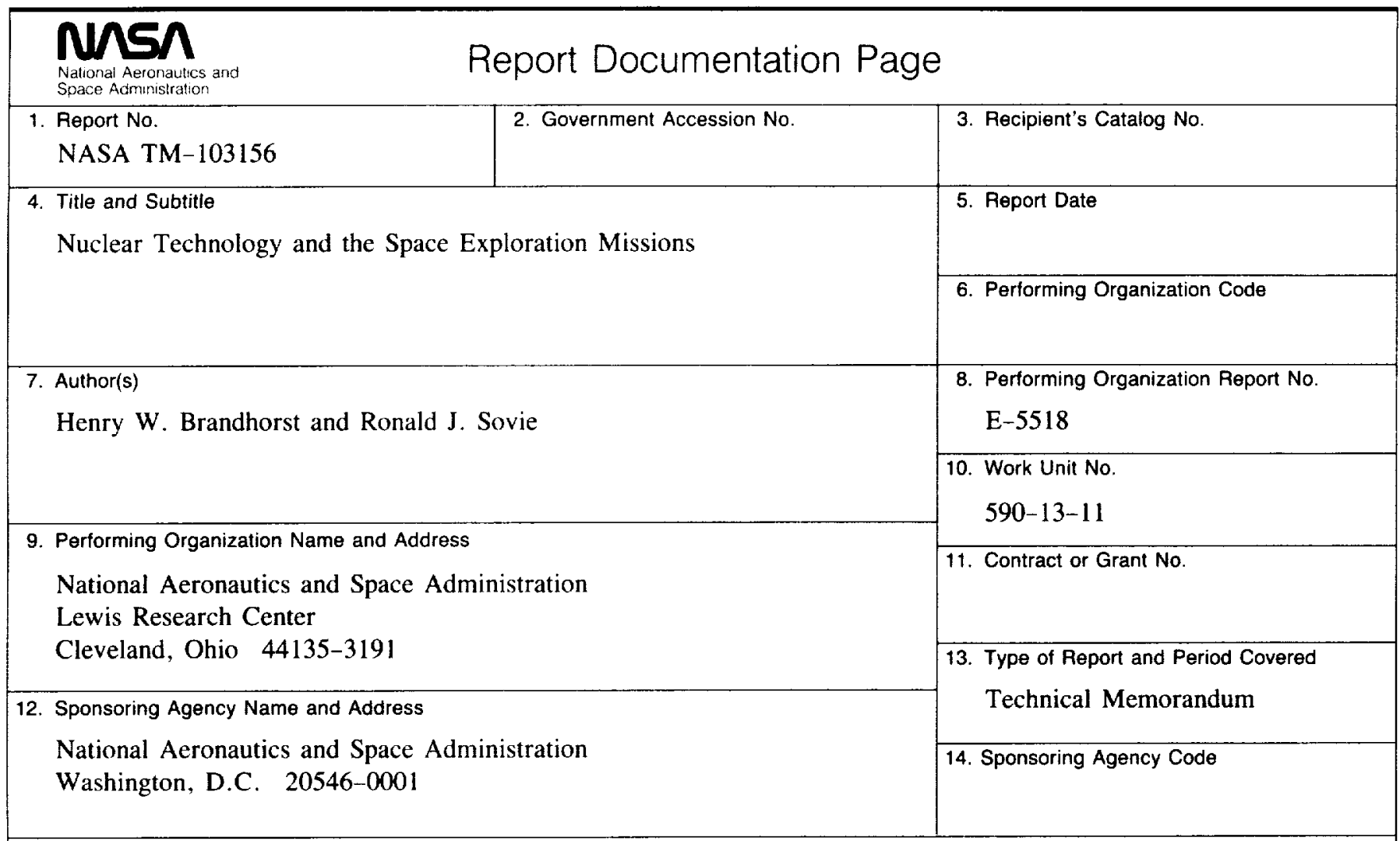

15. Supplementary Notes

Prepared for the 25th Intersociety Energy Conversion Engineering Conference cosponsored by the AIChE, SAE, ACS, AIAA, ASME, and IEEE, Reno, Nevada, August 12-17, 1990.

\section{Abstract}

The strategy for a major exploration initiative leading to permanent human presence beyond earth orbit described by President George Bush July 20, 1989 is still being developed; however enough is known to begin defining the role of nuclear technologies. Three broad areas be discussed: low power $(<10 \mathrm{kWe})$ rover/vehicle power systems, integrated, evolutionary base power systems $(25-100 \mathrm{~kW})$ ind nuclear energy for electric propulsion (2-100 MWe) and direct thermal propulsion (1000s MW). A phased, evolutionary approach witt be described for both the moon and Mars, and the benefits of nuclear technologies relative to solar and their integration witte described.

17. Key Words (Suggested by Author(s))

Nuclear power; Solar power; Propulsion; Mission scenarios; Vehicles; Isotopes; Dynamic conversion; Technologies
18. Distribution Statement

Unclassified - Unlimited

Subject Category 44
19. Security Classif. (of this report)

$$
\text { Unclassified }
$$

20. Security Classif. (of this page)

Unclassified
21. No. of pages

10
22. Price*

A02 